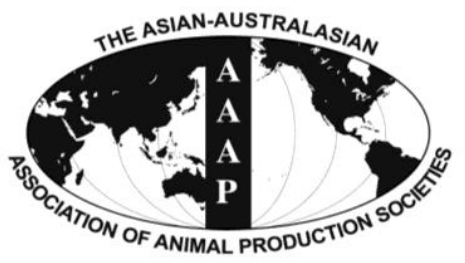

Asian-Aust. J. Anim. Sci.

Vol. 26, No. 2 : 195-201 February 2013

http://dx.doi.org/10.5713/ajas.2012.12378

www.ajas.info

pISSN 101 1-2367 elSSN 1976-5517

\title{
Fermentation Quality of Ensiled Water Hyacinth (Eichhornia crassipes) as Affected by Additives
}

\author{
Ho Thanh Tham*, Ngo Van Man ${ }^{1}$ and Thomas Pauly ${ }^{2}$ \\ Department of Animal Sciences, Can Tho University, Vietnam
}

\begin{abstract}
A lab-scale ensiling study was carried out to investigate the fermentation quality of water hyacinth (WH) supplemented with molasses, rice bran, as an absorbent, and an inoculant in the form of fermented vegetable juice and their combinations. After wilting the water hyacinths for $7 \mathrm{~h}$ to a dry matter (DM) content of 240 to $250 \mathrm{~g} / \mathrm{kg}$, the following treatments were applied: i) Control (C), WH only; ii) WH with sugarcane molasses at $40 \mathrm{~g} / \mathrm{kg} \mathrm{WH}(\mathrm{CM})$; iii) WH inoculated with fermented vegetable juice at $10 \mathrm{ml} / \mathrm{kg} \mathrm{WH}(\mathrm{CI})$; iv) $\mathrm{CM}$ and $\mathrm{CI}(\mathrm{CMI})$ combined; v) WH with $150 \mathrm{~g}$ rice bran/kg WH (CA); vi) CA and CI combined (CAI); vii) CA and CM combined (CAM); and viii) CA, CM and CI combined (CAMI). After application of additives, the differently treated forages were mixed and ensiled in triplicates in 1,500-ml polyethylene jars. After ensiling for $3 \mathrm{~d}$, $\mathrm{pH}$ values in all treatments, except $\mathrm{C}$ and $\mathrm{CI}$, had decreased to approximately 4.0 and remained low till $14 \mathrm{~d}$. After $56 \mathrm{~d}$, $\mathrm{pH}$ had increased between 0.4 to $0.9 \mathrm{pH}$-units compared to those at $14 \mathrm{~d}$. The ammonia nitrogen $\left(\mathrm{NH}_{3}-\mathrm{N}\right)$ concentration ranged from an acceptable level in treatment $\mathrm{CM}(8 \mathrm{~g} / \mathrm{kg} \mathrm{N})$ to a high $\mathrm{NH}_{3}-\mathrm{N}$ value in treatment CMI $(16 \mathrm{~g} / \mathrm{kg} \mathrm{N})$. Lactic acid formation was higher in CI than in all other treatments. Butyric acid contents, which indicate badly fermented silages, were low in all silages $(<2 \mathrm{~g} / \mathrm{kg} \mathrm{DM})$. There were two-way interactions (p-values from $<0.001$ to 0.045$)$ for almost all fermentation end-products and $\mathrm{pH}$, except for the molasses $\times$ inoculant interaction on $\mathrm{NH}_{3}-\mathrm{N}(\mathrm{p}=0.26)$. Significant 3-way interactions were found on all observed variables except for weight losses of silages. It is concluded that conserving wilted WH as silage for ruminants may be improved by the addition of molasses or rice bran. (Key Words: Inoculant, Molasses, Rice Bran, Silage, Water Hyacinth)
\end{abstract}

\section{INTRODUCTION}

Ruminant production plays an important role in the predominantly agricultural economy of Vietnam (Trach, 1998). Due to the extreme scarcity of land for grazing and grass cultivation as well as adequate feeds, particularly in the dry season, the possibility of using fibrous feeds such as crop residues and water hyacinth has become more interesting for the improvement of ruminant production.

Water hyacinth (Eichhornia crassipes) (WH) has become the major floating water weed of tropical and subtropical regions worldwide because of its rapid growth (De Groote et al., 2003). The capacity for vegetative

\footnotetext{
* Corresponding Author: Ho Thanh Tham. Tel: +84-(0)710-387 2057, Fax: +84-(0)710-3830814, E-mail: httham@ctu.edu.vn

${ }^{1}$ Department of Animal Nutrition, Nong Lam University, Ho Chi Minh City, Vietnam.

2 Department of Animal Nutrition and Management, Swedish University of Agricultural Sciences, Kungsängen Research Centre, 75323 Uppsala, Sweden.

Submitted Jul. 7, 2012; Accepted Sept. 25, 2012; Revised Oct. 11, 2012
}

reproduction allows this aquatic plant to quickly occupy all available space (Gutiérrez et al., 1996). Water hyacinth is available all year round and is widespread on freshwater wetlands of the Mekong Delta, especially in standing water (MWBP/RSCP, 2006).

Water hyacinth has received much attention in recent years due to its potential benefits as animal fodder, aquafeed, water purification, fertilizer, biogas production, etc. Numerous studies have evaluated WH as a feed source to ruminants (Baldwin et al., 1975; Abdalla et al., 1987; Agarwala, 1988; Islam et al., 2009; Sophal, 2010), fish (Okoye et al., 2002; Abdel-Fattah, 2003) and other animals (Dey et al., 1983; Men et al., 2002, 2006). Water hyacinth control methods fall into three main categories: physical, chemical and biological (Julien et al., 2001). Its use as a livestock feed is considered as an effective physical control method.

Ensiling aquatic weeds, especially WH, could become important in humid tropical regions where complete drying into hay is difficult (National Academy of Sciences, 1976). Effects of additives on the quality of WH silage have been 
evaluated by some researchers (Byron et al., 1978; Lowilai et al., 1994; 1995; Manh et al., 2002). Effluent should always be avoided because it represents a loss of watersoluble nutrients which may reach $10 \%$ in very wet crops (Wilkins, 2005). To reduce effluents, McDonald et al. (1991) suggested wilting of forage crops to achieve a dry matter (DM) content of 260 to $300 \mathrm{~g} / \mathrm{kg}$. Development of undesirable microorganisms may be reduced, a desirable fermentation will be promoted and livestock intake can be increased by wilting (Grací, 1999).

Additional fermentable carbohydrates are necessary to promote fermentation of most tropical plants and to achieve acceptable silage quality (Bagnall et al., 1974). Sugarcane molasses is used widely for silage making in Vietnam due to its high level of water soluble carbohydrates. This additive has been shown to decrease $\mathrm{pH}$ and ammonia levels in silages (McDonald et al., 2011). As WH has a low DM content, wilting is an option to reduce silage losses. However, weather conditions are not always favourable for adequate wilting, and the use of a suitable absorbent can be considered as an alternative to reduce effluents (McDonald et al., 1991). Rice bran is one of the main by-products of the rice milling industry. It has been used as an absorbent in silage (Lowilai et al., 1995: Yokota et al., 1998) and is readily available in large quantities in the Mekong Delta of Vietnam. Homofermentative lactic acid bacteria (LAB) alone or in combination with heterofermentative $\mathrm{LAB}$ are commonly used as silage additives to improve silage fermentation (McDonald et al., 1991). Inoculation rates of $10^{5}$ to $10^{6}$ colony forming units $(\mathrm{cfu}) / \mathrm{g}$ herbage are often recommended (Henderson, 1993). The effect of adding bacterial inoculants to wilted silage may increase lactic acid production and result in a faster decrease of silage $\mathrm{pH}$ if the forage contains at least $20 \mathrm{~g}$ water soluble carbohydrates (WSC)/kg fresh matter (Pettersson and Lindgren, 1990). Ensiling studies with WH, using additives such as rice bran, cassava root, ground corn, wheat bran (El-Serafy et al., 1989; Lowilai et al., 1993), organic acids (Byron et al., 1975) or urea and rice straw (Wanapat et al., 1985; Chkraborty et al., 1991), have been promising but have not yet been investigated in Vietnam.

The aim of this study was to evaluate the influence of molasses, rice bran and fermented vegetable juice and their combined effects on the fermentation quality of ensiled WH.

\section{MATERIALS AND METHODS}

\section{Study site and experimental design}

The experiment was conducted at Department of Animal Sciences, College of Agriculture and Applied Biology, Can Tho University, Vietnam between March and May 2011. A completely randomized experimental design was used, with eight treatments and three silo replicates for each treatment. Treatments were: i) Control (C), WH only; ii) $\mathrm{WH}$ and sugarcane molasses, at $40 \mathrm{~g} / \mathrm{kg}$ wilted $\mathrm{WH}$ (CM); iii) WH inoculated with fermented vegetable juice at $10 \mathrm{ml} / \mathrm{kg} \mathrm{WH}$ (CI); iv) CM and CI (CMI) combined; v) WH and $150 \mathrm{~g}$ rice bran/kg WH (CA); vi) $\mathrm{CA}$ and $\mathrm{CI}$ combined (CAI); vii) $\mathrm{CA}$ and $\mathrm{CM}$ (CAM) combined; and viii) $\mathrm{CA}$, $\mathrm{CM}$ and $\mathrm{CI}$ combined (CAMI).

Plant material: Water hyacinths at 6 to 7 wks of age were collected along Tien River in Vinh Long province. The petioles were cut 4 to $5 \mathrm{~cm}$ from the base of the plant. Both petiole and leaf fractions were cut by hand into 4 to $5 \mathrm{~cm}$ pieces, spread in a 4 to $5 \mathrm{~cm}$ thick layer on plastic sheeting corresponding to a weight of $4 \mathrm{~kg} / \mathrm{m}^{2}$. The initial dry matter (DM) content was approximately 90 to $110 \mathrm{~g} / \mathrm{kg} \mathrm{WH}$ and the material was sun-dried for approximately $7 \mathrm{~h}$ to a DM content of 240 to $250 \mathrm{~g} / \mathrm{kg}$. The plant material was turned every $30 \mathrm{~min}$ during wilting. Temperature and humidity were recorded every 30 min by a digital thermo-hygrometer (NJ-2099-TH, Nakata, Japan) and ranged from 30 to $42^{\circ} \mathrm{C}$ and 34 to $74 \%$, respectively. During wilting, two representative samples were collected at two occasions to monitor approximate DM changes using a microwave oven (Undersander et al., 1993). The wilted material was subsequently transferred to Can Tho University for ensiling.

Preparation of the inoculants suspension: A local cabbage type vegetable cải be or cải tùa xại (Brassica campestris L.), which is a very popular food item in Vietnam, was acquired from a local market and fermented in the following way. Yellow or rotten leaves were removed and the plants were thoroughly washed and sun-dried for approximately $2 \mathrm{~h}$. The vegetable was first blanched in boiling water for $2 \mathrm{~min}$ to minimize enzyme activity. After blanching, it was drained and immersed in cool sterile water in a capped bucket. Fermentation was done for a period of one week after which one litre of cooled sterile water and 5 $\mathrm{g}$ salt was added to one $\mathrm{kg}$ vegetable. The juice was then extracted by squeezing and filtering.

Mini-silo preparation: The wilted WH was used in the present experiment with or without additives as outlined above. Molasses was collected from a local sugarcane factory. Depending on treatments, the order of addition was: vegetable juice, followed by rice bran and molasses. The wilted material was spread on a plastic sheeting, sprayed with the vegetable juice extract $(10 \mathrm{ml} / \mathrm{kg} \mathrm{WH})$, or "dressed" with rice bran $(150 \mathrm{~g} / \mathrm{kg} \mathrm{WH})$ followed by the addition of molasses $(40 \mathrm{~g} / \mathrm{kg} \mathrm{WH})$. All ingredients were then mixed thoroughly.

A total of $850 \mathrm{~g}$ material was filled into 1500-ml gastight polyethylene jars (Duytan Corp., Ho Chi Minh city, Vietnam). The mixtures were compressed by hand to remove as much air as possible. Lids were sealed with 
silicone caulk. Fermentation gases could escape via waterfilled plastic siphons, which were fitted on the silo lids.

Three mini-silos were prepared for each treatment, giving a total of 24 silos. They were stored indoors at a temperature of 27 to $31^{\circ} \mathrm{C}$ and a relative humidity of 65 to $75 \%$. To follow the $\mathrm{pH}$ changes over time, a second set of silos were made of the same plant material. Two silos per treatment were opened after 3,7 , and $14 \mathrm{~d}$ of storage.

\section{Measurements and laboratory analyses}

Before ensiling, all samples of the mixed material were collected for the analysis of $\mathrm{pH}, \mathrm{DM}$ and chemical composition. Weight losses during storage were determined by weighting the silos. Weights of the filled mini-silos were recorded at 0,3, 7 and $14 \mathrm{~d}$ after filling at 07:30 $\mathrm{h}$ and then at weekly intervals until opening and sampling after $56 \mathrm{~d}$. Mouldy silage found on the surface was discarded before sampling. The contents from each mini-silo were transferred into plastic bags, mixed thoroughly and sampled for chemical analyses.

The silages were analyzed for $\mathrm{pH}$, chemical composition, including fermentation end-products. Concentration of LAB in the fermented vegetable juice and the wilted $\mathrm{WH}$ was determined based on the technique described by International Organization for Standardization (1998) (ISO 15214:1998).

Dry matter content of the wilted and ensiled WH was determined by oven-drying at $105^{\circ} \mathrm{C}$ for $12 \mathrm{~h}$. Dry matter (DM) (967.03), crude protein (CP) (984.13), ash (942.05), acid detergent fibre (ADFom) 973.18), ammonia nitrogen $\left(\mathrm{NH}_{3}-\mathrm{N}\right)(941.04)$ were analyzed as described by AOAC (1990). Neutral detergent fibre (NDFom) was analyzed according to Van Soest et al. (1991). Amylase and sodium sulfite was not used for NDFom determination and both ADFom and NDFom were expressed exclusive of residual ash. Water soluble carbohydrates were analysed following the protocol of Udén (2006). Ethanol, acetic, propionic, butyric and lactic acids were measured by HPLC (Model 10A, Shimadzu Corp., Tokyo, Japan). After opening the mini-silos, $10 \mathrm{~g}$ of silage from each replicate were homogenized in $20 \mathrm{ml}$ distilled water, and $\mathrm{pH}$ of the filtrate was determined using a $\mathrm{pH}$ meter (Mi150, Martini, Romania) with a glass electrode.

\section{Statistical analysis}

Data for each analysis consisted of 2 (levels of molasses $) \times 2$ (levels of rice bran) $\times 2$ (levels of inoculants $) \times 3$ (replicated silos) $=24$. All observations were used in the analysis of variance of chemical composition, fermentation quality and weight loss of silage DM. The GLM procedure of Minitab software, version 16.1 (Minitab Inc., 2010) was used and with the following model of fixed factors and their interactions:

$$
\mathrm{Y}_{\mathrm{ijkl}}=\mu+\mathrm{M}_{\mathrm{i}}+\mathrm{A}_{\mathrm{j}}+\mathrm{I}_{\mathrm{k}}+\mathrm{MA}_{\mathrm{ij}}+\mathrm{MI}_{\mathrm{ik}}+\mathrm{AI}_{\mathrm{jk}}+\mathrm{MAI}_{\mathrm{ijk}}+\mathrm{e}_{\mathrm{ijkl}}
$$

where $\mathrm{Y}_{\mathrm{ijkl}}=$ the dependent variable, $\mu=$ the overall mean, $M_{i}=$ effect of sugarcane molasses, $A_{j}=$ effect of rice bran as absorbent, $I_{k}=$ effect of inoculants and $e_{i j k l}=$ the random error.

Pearson correlation coefficients among all dependent variables were also calculated using the same software.

\section{RESULTS}

\section{Chemical composition of silage ingredients}

The chemical composition of the wilted $\mathrm{WH}$, rice bran and sugarcane molasses is shown in Table 1. Rice bran and molasses had a DM content of 920 and $814 \mathrm{~g} / \mathrm{kg}$, respectively, and wilted WH before ensiling had a DM content of $244 \mathrm{~g} / \mathrm{kg}$. The initial content of WSC was 4.3 $\mathrm{g} / \mathrm{kg} \mathrm{DM}$ in wilted WH. Concentrations of LAB in the fermented vegetable juice and the wilted WH were $2.1 \times 10^{7}$ $\mathrm{cfu} / \mathrm{ml}$ and $1.2 \times 10^{7} \mathrm{cfu} / \mathrm{g}$ wilted $\mathrm{WH}$, respectively.

\section{The fermentation quality of the silages}

No free liquid or effluent was found in any of the minisilos. On visual inspection (d 56), spoilage moulds were found on the top of $\mathrm{C}$ and $\mathrm{CA}$ silos. Mould development was virtually absent in CAM silage, while the remaining silages of CM, CI, CMI, CAI and CAMI had little or no mould growth. Silage colour was greenish yellow and changed to a brownish yellow colour after $56 \mathrm{~d}$ of storage. Addition of rice bran caused increase in DM content from 242 to $301 \mathrm{~g} / \mathrm{kg}$ and by adding molasses, it was increased further to $334 \mathrm{~g} / \mathrm{kg}$ (Table 2). The results show differences among treatments for all variables $(\mathrm{p}<0.001)$. Both rice bran and molasses increased WSC levels, each by approximately $5 \mathrm{~g} / \mathrm{kg}$ DM. Rice bran predictably decreased CP and NDFom contents $(\mathrm{p}<0.001)$.

There were overall differences $(\mathrm{p}<0.001)$ among treatments in $\mathrm{pH}$, fermentation end-products and weight

Table 1. Dry matter and chemical composition (g/kg DM) of the wilted water hyacinth, rice bran and sugarcane molasses $(n=3)$

\begin{tabular}{|c|c|c|c|c|c|c|}
\hline \multirow[t]{2}{*}{ Item $^{a}$} & \multicolumn{2}{|c|}{ Water hyacinth } & \multicolumn{2}{|c|}{ Rice bran } & \multicolumn{2}{|c|}{$\begin{array}{c}\text { Sugarcane } \\
\text { molasses }\end{array}$} \\
\hline & Mean & SD & Mean & SD & Mean & SD \\
\hline Dry matter & 244 & 0.83 & 920 & 1.26 & 814 & 4.22 \\
\hline Crude protein & 155 & 0.61 & 82 & 0.52 & 33 & 0.91 \\
\hline Ash & 165 & 1.45 & 117 & 0.27 & 64 & 0.47 \\
\hline ADFom & 364 & 1.66 & 337 & 1.20 & nd & nd \\
\hline NDFom & 622 & 3.81 & 479 & 22.1 & nd & nd \\
\hline WSC & 4.3 & - & nd & nd & nd & nd \\
\hline
\end{tabular}

a ADFom = Acid detergent fibre; NDFom = Neutral detergent fibre; WSC = Water soluble carbohydrates; $\mathrm{nd}=$ Not determined. 
Table 2. Dry matter (DM) and concentrations (g/kg DM) of water soluble carbohydrates (WSC), crude protein (CP), neutral detergent fibre (NDFom) and ash of water hyacinth (WH) silages after ensiling for $56 \mathrm{~d}(\mathrm{n}=3)$

\begin{tabular}{|c|c|c|c|c|c|c|c|c|c|c|}
\hline & \multicolumn{8}{|c|}{ Treatments* } & \multirow{2}{*}{ SEM } & \multirow{2}{*}{$\mathrm{p}$} \\
\hline & $\mathrm{C}$ & $\mathrm{CM}$ & CI & CMI & $\mathrm{CA}$ & CAI & CAM & CAMI & & \\
\hline $\mathrm{DM}$ & $242^{g}$ & $258^{\mathrm{e}}$ & $234^{\mathrm{h}}$ & $252^{f}$ & $301^{d}$ & $306^{c}$ & $334^{\mathrm{a}}$ & $318^{\mathrm{b}}$ & 0.57 & $<0.001$ \\
\hline WSC & $0.7^{\mathrm{c}}$ & $1.1^{\mathrm{c}}$ & $0.4^{\mathrm{c}}$ & $1.1^{\mathrm{c}}$ & $5.4^{\mathrm{b}}$ & $6.9^{\mathrm{b}}$ & $12.1^{\mathrm{a}}$ & $11.4^{\mathrm{a}}$ & 0.52 & $<0.001$ \\
\hline $\mathrm{CP}$ & $157^{\mathrm{a}}$ & $164^{\mathrm{a}}$ & $156^{\mathrm{a}}$ & $156^{\mathrm{a}}$ & $139^{\mathrm{b}}$ & $136^{\mathrm{b}}$ & $135^{\mathrm{b}}$ & $139^{\mathrm{b}}$ & 1.82 & $<0.001$ \\
\hline NDFom & $587^{\mathrm{a}}$ & $500^{\mathrm{d}}$ & $584^{\mathrm{a}}$ & $520^{\mathrm{c}}$ & $557^{\mathrm{b}}$ & $549^{\mathrm{b}}$ & $529^{c}$ & $522^{c}$ & 3.04 & $<0.001$ \\
\hline Ash & $180^{\mathrm{a}}$ & $164^{b c}$ & $178^{\mathrm{a}}$ & $174^{\mathrm{ab}}$ & $153^{\mathrm{cd}}$ & $160^{\mathrm{cd}}$ & $152^{\mathrm{d}}$ & $152^{\mathrm{d}}$ & 2.36 & $<0.001$ \\
\hline
\end{tabular}

* $\mathrm{C}=\mathrm{WH}$ only (Control); $\mathrm{CM}=\mathrm{C}+40 \mathrm{~g}$ sugarcane molasses $/ \mathrm{kg} \mathrm{WH} ; \mathrm{CI}=\mathrm{C}+10 \mathrm{ml}$ inoculant $/ \mathrm{kg} \mathrm{WH}$ CMI = CM+CI; CA = C+150 g rice bran/kg WH; $\mathrm{CAI}=\mathrm{CA}+\mathrm{CI} ; \mathrm{CAM}=\mathrm{CA}+\mathrm{CM} ; \mathrm{CAMI}=\mathrm{CA}+\mathrm{CM}+\mathrm{CI}$.

$\mathrm{SEM}=$ Standard error of means. ${ }^{\text {a,b,c,d,e,f,g,h }}$ Means within rows with different letters differ $(\mathrm{p}<0.05)$.

Table 3. Fermentation end-product concentrations, $\mathrm{pH}$ and weight losses in water hyacinth $(\mathrm{WH})$ silages after 56 days of ensiling ( $\mathrm{g} / \mathrm{kg}$ DM or as otherwise stated) after addition of molasses (M), absorbent (A), inoculants (I) or combinations

\begin{tabular}{|c|c|c|c|c|c|c|c|c|c|c|c|c|c|c|c|c|c|}
\hline \multirow{2}{*}{ Item } & \multicolumn{8}{|c|}{ Treatments* } & \multirow{2}{*}{ SEM } & \multirow{2}{*}{$\mathrm{p}$} & \multicolumn{7}{|c|}{$\mathrm{p}$} \\
\hline & $\mathrm{C}$ & $\mathrm{CM}$ & $\mathrm{CI}$ & CMI & $\mathrm{CA}$ & CAI & CAM & CAMI & & & $\mathrm{M}$ & A & $\mathrm{I}$ & $\mathrm{M} \times \mathrm{A}$ & $\mathrm{M} \times \mathrm{I}$ & $\mathrm{A} \times \mathrm{I}$ & $\mathrm{M} \times \mathrm{A} \times \mathrm{I}$ \\
\hline Lactic acid & $10.9^{\mathrm{h}}$ & $21.1^{\mathrm{f}}$ & $95.4^{\mathrm{a}}$ & $11.7^{\mathrm{g}}$ & $60.4^{\mathrm{c}}$ & $69.2^{\mathrm{b}}$ & $44.9^{\mathrm{d}}$ & $40.2^{\mathrm{e}}$ & 0.06 & $<0.001$ & $<0.001$ & $<0.001$ & $<0.001$ & $<0.001$ & $<0.001$ & $<0.001$ & $<0.001$ \\
\hline Acetic acid & $1.5^{\mathrm{b}}$ & $2.0^{\mathrm{a}}$ & $1.0^{\mathrm{c}}$ & $1.6^{\mathrm{b}}$ & $1.0^{\mathrm{c}}$ & $0.7^{\mathrm{d}}$ & $1.0^{\mathrm{c}}$ & $0.9^{\mathrm{c}}$ & 0.03 & $<0.001$ & $<0.001$ & $<0.001$ & $<0.001$ & $<0.001$ & 0.005 & $<0.001$ & 0.653 \\
\hline Propionic acid & $0.4^{\mathrm{f}}$ & $1.5^{\mathrm{a}}$ & $0.2^{\mathrm{g}}$ & $1.0^{\mathrm{c}}$ & $0.7^{\mathrm{d}}$ & $0.5^{\mathrm{e}}$ & $1.3^{\mathrm{b}}$ & $1.0^{\mathrm{c}}$ & 0.02 & $<0.001$ & $<0.001$ & $<0.001$ & $<0.001$ & $<0.001$ & $<0.001$ & 0.015 & $<0.001$ \\
\hline Butyric acid & $0.3^{\mathrm{g}}$ & $1.4^{\mathrm{d}}$ & $1.6^{b c}$ & $1.7^{\mathrm{b}}$ & $1.5^{\mathrm{c}}$ & $0.4^{\mathrm{f}}$ & $1.9^{\mathrm{a}}$ & $0.9^{\mathrm{e}}$ & 0.02 & $<0.001$ & $<0.001$ & $<0.001$ & $<0.001$ & $<0.001$ & $<0.001$ & $<0.001$ & $<0.001$ \\
\hline Ethanol & $0.5^{\mathrm{a}}$ & $0.2^{\mathrm{c}}$ & $0.3^{\mathrm{b}}$ & $0.2^{\mathrm{cd}}$ & $0.2^{\mathrm{c}}$ & $0.1^{\mathrm{d}}$ & $0.2^{\mathrm{b}}$ & $0.2^{\mathrm{c}}$ & 0.01 & $<0.001$ & $<0.001$ & $<0.001$ & $<0.001$ & $<0.001$ & $<0.001$ & 0.006 & $<0.001$ \\
\hline $\mathrm{pH}$ & $5.4^{\mathrm{a}}$ & $4.9^{\mathrm{cd}}$ & $5.2^{\mathrm{b}}$ & $4.6^{\mathrm{f}}$ & $4.9^{\mathrm{c}}$ & $4.7^{\mathrm{e}}$ & $4.8^{\mathrm{de}}$ & $4.8^{\mathrm{de}}$ & 0.02 & $<0.001$ & $<0.001$ & $<0.001$ & 0.001 & $<0.001$ & 0.045 & 0.010 & 0.002 \\
\hline $\mathrm{NH}_{3}-\mathrm{N}(\mathrm{g} / \mathrm{kg} \mathrm{N})$ & $15.2^{\mathrm{a}}$ & $8.4^{\mathrm{c}}$ & $14.4^{\mathrm{a}}$ & $15.6^{\mathrm{a}}$ & $11.2^{\mathrm{b}}$ & $13.4^{\mathrm{ab}}$ & $14.7^{\mathrm{a}}$ & $10.9^{\mathrm{bc}}$ & 0.55 & $<0.001$ & 0.01 & 0.05 & 0.007 & 0.001 & 0.259 & $<0.001$ & $<0.001$ \\
\hline Weight loss & $39.8^{\mathrm{a}}$ & $35.0^{\mathrm{ab}}$ & $42.0^{\mathrm{a}}$ & $45.2^{\mathrm{a}}$ & $26.1^{\mathrm{bc}}$ & $22.4^{\mathrm{c}}$ & $18.2^{\mathrm{c}}$ & $21.0^{\mathrm{c}}$ & 2.45 & $<0.001$ & 0.135 & $<0.001$ & 0.115 & 0.281 & 0.054 & 0.075 & 0.84 \\
\hline
\end{tabular}

* $\mathrm{C}=\mathrm{WH}$ only (control); $\mathrm{CM}=\mathrm{C}+40 \mathrm{~g}$ sugarcane molasses $/ \mathrm{kg} \mathrm{WH}$; $\mathrm{CI}=\mathrm{C}+10 \mathrm{ml}$ inoculant $/ \mathrm{kg} \mathrm{WH}$; $\mathrm{CMI}=\mathrm{CM}+\mathrm{CI}$; $\mathrm{CA}=\mathrm{C}+150 \mathrm{~g}$ rice bran/kg WH; $\mathrm{CAI}=\mathrm{CA}+\mathrm{CI} ; \mathrm{CAM}=\mathrm{CA}+\mathrm{CM} ; \mathrm{CAMI}=\mathrm{CA}+\mathrm{CM}+\mathrm{CI}$.

$\mathrm{SEM}=$ Standard error of means. ${ }^{a}, \mathrm{~b}, \mathrm{c}, \mathrm{d}, \mathrm{e}, \mathrm{f}, \mathrm{g}, \mathrm{h}$ Means within rows with different letters differ $(\mathrm{p}<0.05)$.

losses (Table 3). All additives influenced the formation of end-products and $\mathrm{pH}(\mathrm{p}<0.001)$. There were also two-way interactions ( $\mathrm{p}$-values from $<0.001$ to 0.045 ) for almost all fermentation end-products and $\mathrm{pH}$ except for the molasses $\times$ inoculant interaction on $\mathrm{NH}_{3}-\mathrm{N}(\mathrm{p}=0.26)$. Significant $3-$ way interactions were found on all observed variables except for weight losses of silage.

Ammonia nitrogen levels in silages were significantly decreased by the addition of molasses (M) and rice bran (A) but not by inoculants (I), while weight losses were decreased only by rice bran. Lactic acid formation was higher $(\mathrm{p}<0.001)$ in CI $(95.4 \mathrm{~g} / \mathrm{kg} \mathrm{DM})$ than in all other treatments. Butyric acid contents were relatively low, with the highest value in CAM (1.9 g/kg DM) and the lowest value in $\mathrm{C}(0.3 \mathrm{~g} / \mathrm{kg} \mathrm{DM})$. Ammonia nitrogen differed among treatments $(\mathrm{p}<0.001)$, with treatment $\mathrm{CM}$ giving the lowest value $(8.4 \mathrm{~g} / \mathrm{kg} \mathrm{N})$, and treatment CMI giving the highest value $(15.6 \mathrm{~g} / \mathrm{kg} \mathrm{N})$.

After ensiling for $7 \mathrm{~d}, \mathrm{pH}$ values in all treatments, except $\mathrm{C}$ and CI, had decreased to approximately 4.0 and remained on that level until at least d 14 (Figure 1). After 56 $\mathrm{d}, \mathrm{pH}$ had increased to approximately 4.8. Both $\mathrm{C}$ and CI silages decreased only to $\mathrm{pH} 5.0$ and 4.5 , respectively, at $\mathrm{d} 7$ and then increased between 14 and $56 \mathrm{~d}$ to approximately

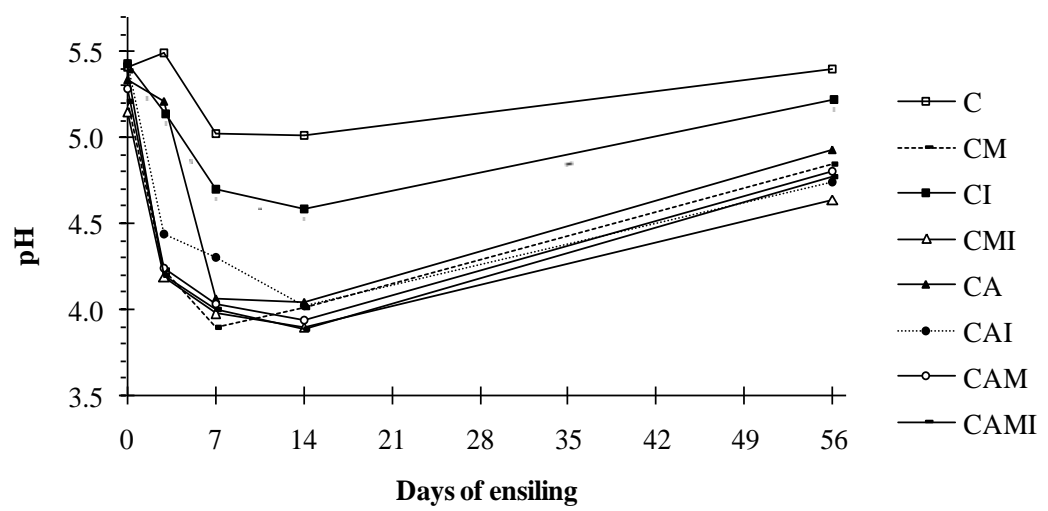

Figure 1. Changes in $\mathrm{pH}$ during ensilage of water hyacinth $(\mathrm{WH}) . \mathrm{C}=\mathrm{WH}$ only (control); $\mathrm{CM}=\mathrm{C}+40 \mathrm{~g}$ sugarcane molasses $/ \mathrm{kg}$ WH; $\mathrm{CI}$ $=\mathrm{C}+10 \mathrm{ml}$ inoculant $/ \mathrm{kg} \mathrm{WH} ; \mathrm{CMI}=\mathrm{CM}+\mathrm{CI} ; \mathrm{CA}=\mathrm{C}+150 \mathrm{~g}$ rice bran $/ \mathrm{kg} \mathrm{WH} ; \mathrm{CAI}=\mathrm{CA}+\mathrm{CI} ; \mathrm{CAM}=\mathrm{CA}+\mathrm{CM} ; \mathrm{CAMI}=\mathrm{CA}+\mathrm{CM}+\mathrm{CI}$. 


\section{3 (Figure 1).}

\section{DISCUSSION}

Because of its rapid spoilage and high moisture content, it is recommended to wilt WH in the shade for $2 \mathrm{~d}$ (Göhl, 1981). Prolonged wilting of crops has been shown to result in lower WSC of the crop (Uchida et al., 1989; Pettersson and Lindgren, 1990), and to reduce acetic acid and $\mathrm{NH}_{3}-\mathrm{N}$ production (Liu et al., 2011).

As shown in Figure 1, the $\mathrm{pH}$ of treatment CI gradually decreased from d 3 until d 14. Applying fermented juice made from fresh alfalfa and glucose fermented for $2 \mathrm{~d}$ was shown to improve alfalfa silage quality (Ohshima et la., 1997). In our study, inoculation with LAB from fermented vegetable juice did not initiate a desirable fermentation of WH with an inherently low WSC content $(4 \mathrm{~g} / \mathrm{kg} \mathrm{DM})$. It is well known that WSC content is a crucial and limiting factor of silage fermentation (Liu et al., 2011). Haigh and Parker (1985) regarded 25 to $35 \mathrm{~g} / \mathrm{kg}$ in fresh herbage as minimal WSC concentrations for successful ensiling of unwilted herbage. The WSC contents of wilted WH in the present study and molasses according to McDonald et al. (2011), was 4 and $700 \mathrm{~g} / \mathrm{kg} \mathrm{DM}$, respectively. Based on values above, an addition of $40 \mathrm{~g}$ molasses to the wilted WH would result in approximately $24 \mathrm{~g} \mathrm{WSC} / \mathrm{kg}$ in the CM mixture ( $1 \mathrm{~g}$ from $\mathrm{WH}$ and $23 \mathrm{~g}$ from molasses). The addition of $40 \mathrm{~g}$ molasses per $\mathrm{kg}$ WH should therefore supply enough WSC to avoid any shortage of substrate during the fermentation process. The $\mathrm{pH}$ course over time in Figure 1 confirms that since only treatments $\mathrm{C}$ and $\mathrm{CI}$ appeared to lack WSC, which made it difficult for the LAB to reduce silage $\mathrm{pH}$ to the same level in the other treatments. Figure 1 indicates further that the addition of rice bran (A) had a similar effect on the WSC level of the WH silage as the addition of molasses. Manh et al. (2002) found that WH (15\% DM) was successfully preserved by adding $4.5 \%$ of molasses (fresh matter basis). After ensiling for $3 \mathrm{~d}$, the $\mathrm{pH}$ value had decreased from 5.1 to 4.0 and remained stable for $30 \mathrm{~d}$. Rice bran contains only $53 \mathrm{~g} \mathrm{WSC} / \mathrm{kg}$ DM compared to $700 \mathrm{~g} \mathrm{WSC} / \mathrm{kg}$ DM in molasses (Lowilai et al., 1994; McDonald et al., 2011). Even when the amount of applied rice bran was 4 to 5 times higher than molasses, the WSC contribution from rice bran was only approximately $7 \mathrm{~g} / \mathrm{kg}$ forage. Molasses will therefore promote fermentation more than rice bran (Ngoan et al., 2000). Silage pH is a standard indicator for the course of fermentation. However, it is heavily influenced by the DM content which means that it is only applicable as an indicator at lower DM contents (Weissbach, 1996). At higher DM contents, silages stabilise at a higher $\mathrm{pH}$ values (Leibeinsperger and Pitt, 1988). If the $\mathrm{pH}$ fall is insufficient to prevent development of coliform and clostridial bacteria, it may rise again (Wilkinson, 2005).
However, the lack of butyrate in our silages excludes clostridia as the causative agents. Mould growth in the top layer of some of our silos suggests that yeasts and moulds might have been stimulated by the ingress of small amounts of air (Elferink et al., 1999). These fungi are able to metabolize lactate in the presence of oxygen, which eventually will lead to increased $\mathrm{pH}$ values in silages. The $\mathrm{NH}_{3}-\mathrm{N}$ concentration in silage reflects the degree of amino acid degradation (Driehuis et al., 2001) if ammonia formation from nitrate and nitrite in the forage is considered. An acceptable level of $\mathrm{NH}_{3}-\mathrm{N}$ in silage should be below $110 \mathrm{~g} / \mathrm{kg} \mathrm{N}$ (Church, 1991) which only CM and CAMI silages achieved. Slightly increased ammonia levels should however not be harmful to cattle, if the animals' production level is not very high.

Although commercial inoculants have proved effective in improving silage fermentation (Weinberg and Muck, 1996; Arriola et al., 2011), successful control of fermentation depends on several factors, primarily the inoculation rate (at least $10^{5} \mathrm{cfu} / \mathrm{g}$ fresh crop), and the presence of an adequate level of WSC (Islam et al., 2011; McDonald et al., 2011).

There are only a limited number of reports on feeding WH to animals. Pigs showed an immediate acceptance of WH without drying (Men et al., 2006) while Islam et al. (2011) claimed that a major constraint for its use as a ruminant feed is the high water content. Cattle preferred WH silage containing the highest level of additives, $4 \mathrm{~kg}$ dried citrus pulp and $1 \mathrm{~kg}$ sugarcane molasses $/ 100 \mathrm{~kg}$ pressed WH residue (Baldwin et al., 1974). However, the higher butyric acid contents of the aquatic plant silages may have a depressing effect on DM intake (Linn et al., 1975). In the present study, the CAM silage had the highest level of butyric acid (1.9 $\mathrm{g} / \mathrm{kg} \mathrm{DM})$, which was below the acceptable limit of $2 \mathrm{~g} / \mathrm{kg}$ DM silage stated by Castle and Watson (1985).

During feed scarcity period in the dry season, WH could be ensiled for ruminant feeding. An additional carbohydrate source such as molasses, $4 \%$ as shown in this research, is necessary to produce acceptable silage. Baldwin et al. (1975) failed to get a good fermentation quality with WH due to excessive losses of soluble material in the effluents. The addition of suitable absorbents to reduce moisture content and to minimise WSC losses with the effluent are therefore needed. Absorbents have the additional advantage that the wilting process can be shortened or omitted and that the silage can be supplemented with suitable nutrients. Yokota et al. (1998) found that a combination of molasses and rice bran improved fermentation quality of ensiled napier grass (Pennisetum purpureum Schum.) more than each additive alone. Although the $\mathrm{pH}$ values of the silages were not as low as expected even in the best treatments, the silages were preserved well as illustrated by low acetic and 
butyric acid as well as $\mathrm{NH}_{3}-\mathrm{N}$ concentrations. Water hyacinths were successfully ensiled with either $4 \%$ of sugarcane molasses, $15 \%$ of rice bran (fresh weight basis) or with a combination of the two additives. The best fermentation quality in the present study was achieved with silage treatments CM, CA and CAMI. Both rice bran and molasses are readily available all year round, but rice bran is more expensive than molasses. If the choice stands between molasses or rice bran, then molasses should be the first choice with regard to improving silage fermentation.

\section{CONCLUSIONS}

The present results suggest that there are marked influences on the formation of end-products and on $\mathrm{pH}$ in WH silages by addition of molasses or rice bran. The good results obtained in lab-scale silos suggest that the ensiling of $\mathrm{WH}$ on a larger scale could be a viable alternative to farmers and ensiled WH could serve as a source of roughage for ruminants in the tropics. Focus should be put on the maintenance of anaerobic conditions in silos because that is a vital precondition for good fermentation quality. Under practical conditions, the advantages of these additives must be balanced against their cost and efficacy.

\section{ACKNOWLEDGEMENTS}

This work was funded by the Sida-SAREC Mekong Basin Animal Research Network (MEKARN). We would like to thank Pham My Ngoan for her help in carrying out the study and chemical analyses.

\section{REFERENCES}

Abdalla, A. L., E. J. Ambrosano, D. M. S. S. Vitti and F. J. C. Silva. 1987. Water-hyacinth (Eichhornia crassipes) in ruminant nutrition. Water Sci. Technol. 19:109-112.

Abdel-Fattah, M. E.-S. 2003. Effects of fermentation methods on the nutritive value of water hyacinth for Nile tilapia Oreochromis niloticus (L.) fingerlings. Aquaculture 218:471478.

Agarwala, O. N. 1988. Water hyacinth (Eichhornia crassipes) silage as cattle feed. Biol. Waste. 24:71-73.

AOAC. 1990. Official methods of analysis (15th ed.). Association of Official Analytical Chemists Inc., Virginia, USA.

Arriola, K. G., S. C. Kim and A. T. Adesogan. 2011. Effect of applying inoculants with heterolactic or homolactic and heterolactic bacteria on the fermentation and quality of corn silage. J. Dairy Sci. 94:1511-1516.

Bagnall, L. O., J. A. Baldwin and J. F. Hentges. 1974. Processing and storage of waterhyacinth silage. Hyacinth Control J. 12:73-79.

Baldwin, J. A., J. F. Hentges and L. O. Bagnall. 1974. Preservation and cattle acceptability of water hyacinth silage. Hyacinth Control J. 12:79-81.
Baldwin, J. A., J. F. Hentges, L. O. Bagnall and R. L. Shirley. 1975. Comparison of pangolagrass and water hyacinth silages as diets for sheep. J. Anim. Sci. 40:968-971.

Byron, H. T., J. R. James F Hentges, J. D. O'connell and L. O. Bagnall. 1975. Organic acid preservation of waterhyacinth silage. Hyacinth Control J. 13:64-66.

Castle, M. E. and J. N. Watson. 1985. Silage and milk production: studies with molasses and formic acid as additives for grass silage. Grass Forage Sci. 40:85-92.

Chakraborty, B., P. Biswas, L. Mandal and G. C. Banerjee. 1991. Effect of feeding fresh water hyacinth (Eichhorinia crassipes) or its silage on the milk production in crossbred cows. Indian J. Anim. Sci. 8:115-118.

De Groote, H., O. Ajuonu, S. Attignon, R. Djessou and P. Neuenschwander. 2003. Economic impact of biological control of water hyacinth in Southern Benin. Ecol. Econ. 45:105-117.

Dey, B. C., M. A. Hamid and S. D. Chowdhury. 1983. Effect of boiled sesame-cake and water-hyacinth leaves on the performance of ducklings. Indian J. Anim. Sci. 53:988-990.

Driehuis, F., S. J. W. H. Oude Elferink and P. G. Van Wikselaar. 2001. Fermentation characteristics and aerobic stability of grass silage inoculated with Lactobacillus buchneri, with or without homofermentative lactic acid bacteria. Grass Forage Sci. 56:330-343.

El-Serafy, A. M., M. Shoukry, S. Mansour, H. S. Soliman, H. M. Aly and M. A. El-Ashry. 1989. A new potential roughage source for ruminants in Egypt: Processing and utilization of water hyacinth as hay or silage. In: Ruminant production in the dry subtropics: constraints and potentials. Proceedings of the International Symposium on the Constraints and Possibilities of Ruminant Production in the Dry Subtropics (MOA of Egypt, ESAP, EAAP, FAO, ICAMAS, WAAP), Cairo, Egypt, 5-7 November 1988. pp. 153-155.

Elferink, S. J. W. H. O., F. Driehuis, J. C. Gottschal and S. F. Spoelstra. 1999. Silage fermentation processes and their manipulation. In: FAO Electronic Conference on Tropical Silage, 1 Sep-15 Dec 1999. Paper 2.

García, F. O. 1999. Harvesting and ensiling techniques. In: FAO Electronic Conference on Tropical Silage, 1 Sep-15 Dec 1999. Paper 8.

Göhl, B. 1981. Tropical Feeds: Feed Information Summaries and Nutritive Values. Food and Agriculture Organization of the United Nations, Roma, Italy.

Gutiérrez, E., R. Huerto, P. Saldaña and F. Arreguín. 1996. Strategies for waterhyacinth (Eichhornia crassipes) control in Mexico. Hydrobiologia 340:181-185.

Haigh, P. M. and J. W. G. Parker. 1985. Effect of silage additives and wilting on silage fermentation, digestibility and intake, and on liveweight change of young cattle. Grass Forage Sci. 40:429-436.

Henderson, N. 1993. Silage additives. Anim. Feed Sci. Technol. 45:35-56

International Organization for Standardization. 1998. Microbiology of food and animal feeding stuffs - Horizontal method for the enumeration of mesophilic lactic acid bacteriacolony-count technique at 30 degrees C (ISO 15214:1998). Switzerland.

Islam, S., M. N. Islam and J. Khan. 2011. Aquatic plants as cattle feed with special reference to water hyacinth: Nutrient 
Composition and Effect of Feeding Wilted Water Hyacinth (Eichhornia crassipes) on the Performance of Bull Calves. LAP LAMBERT Academic Publishing, Saarbrücken, Germany. Islam, S., M. J. Khan and M. N. Islam. 2009. Effect of feeding wilted water hyacinth (Eichhornia crassipes) on the performance of growing bull cattle. Indian J. Anim. Sci. 79:494-497.

Julien, M. H., M. W. Griffiths and J. N. Stanley. 2001. Biological control of water hyacinth 2. The moths Niphograpta albiguttalis and Xubida infusellus: biologies, host ranges, and rearing, releasing and monitoring techniques. Canberra, Australia. ACIAR Monograph No. 79.

Leibeinsperger, R. Y. and R. E. Pitt. 1988. Modeling the effects of formic acid and molasses on ensilage. J. Dairy Sci. 71:12201231.

Linn, J. G., R. D. Goodrich, D. E. Otterby, J. C. Meiske and E. J. Staba. 1975. Nutritive value of dried or ensiled aquatic plants. II. Digestibility by sheep. J. Anim. Sci. 41:610-615.

Liu, Q., J. Zhang, S. Shi and Q. Sun. 2011. The effects of wilting and storage temperatures on the fermentation quality and aerobic stability of stylo silage. Anim. Sci. J. 82:549-553.

Lowilai, P., K. Kabata, C. Okamoto and M. Kikuchi. 1993. Effects of cassava roots on water hyacinth silage. J. Japan. Grassl. Sci. 39:263-266.

Lowilai, P., K. Kabata, C. Okamoto and M. Kikuchi. 1994. Effects of rice bran and wheat bran on fermentation quality and chemical composition of water hyacinth silage. J. Japan. Grassl. Sci. 40:271-277.

Lowilai, P., K. Kabata, C. Okamoto and M. Kikuchi. 1995. The feeding value of water hyacinth silage added rice bran. Grass Forage Sci. 41:16-20.

Manh, L. H., N. N. X. Dung and S. Yamasaki. 2002. Water hyacinth (Eichhornia crassipes): Ensiling techniques, its composition and intake of pigs. In: Technology Development for Livestock Production - The 2002 Annual Workshop of JIRCAS, Can Tho, Vietnam. pp. 168-175.

McDonald, P., R. A. Edwards, J. F. D. Greenhalgh, C. A. Morgan, L. A. Sinclair and R. G. Wilkinson. 2011. Animal Nutrition. 7th edn. Pearson, Harlow, England.

McDonald, P., N. Henderson and S. Heron. 1991. The Biochemistry of Silage. 2nd edn. Chalcombe Publications, Marlow, Bucks, England.

Men, B. X., B. Ogle and J. E. Lindberg. 2002. Effect of diet and management system on growing duck performance in the Mekong Delta of Vietnam. J. Sustain. Agric. 20:21-32.

Men, L. T., S. Yamasaki, J. S. Caldwell, R. Yamada, R. Takada and T. Taniguchi. 2006. Effect of farm household income levels and rice-based diet or water hyacinth (Eichhornia crassipes) supplementation on growth/cost performances and meat indexes of growing and finishing pigs in the Mekong Delta of Vietnam. Anim. Sci. J. 77:320-329.

Minitab Inc. 2010. Minitab Statistical Software, version 16.1.0. State College, Pennsylvania, USA.

MWBP/RSCP. 2006. Invasive Alien Species in the Lower Mekong Basin: Current State of Play. Mekong Wetland Biodiversity Programme and Regional Species Conservation Programme, The World Conservation Union (IUCN), Asia, Sri Lanka.

National Academy of Sciences. 1976. Making Aquatic Weeds Useful: Some Perspectives for Developing Countries.
Washington DC, USA.

Ngoan, L. D., L. V. An, B. Ogle and J. E. Lindberg. 2000. Ensiling techniques for shrimp by-products and their nutritive value for pigs. Asian-Aust. J. Anim. Sci. 13:1278-1284.

Ohshima, M., E. Kimura and H. Yokota. 1997. A method of making good quality silage from direct cut alfalfa by spraying previously fermented juice. Anim. Feed Sci. Technol. 66:129137.

Okoye, F. C., F. Daddy and B. D. Ilesanmi. 2002. The nutritive value of water hyacinth (Eichhornia crassipes) and its utilisation in fish feed. In: Proceedings of the International Conference on Water Hyacinth, 27 Nov - 1 Dec 2000, New Bussa, Nigeria. pp. 65-70.

Pettersson, K. L. and S. Lindgren. 1990. The influence of the carbohydrate fraction and additives on silage quality. Grass Forage Sci. 45:223-233.

Sophal, C. 2010. Effects of supplements of water hyacinth and cassava hay on the performance of local "yellow" cattle fed a basal diet of rice straw. Master thesis, Swedish University of Agricultural Sciences, Uppsala, Sweden.

Trach, N. X. 1998. The need for improved utilisation of rice straw as feed for ruminants in Vietnam: An overview. Livest. Res. Rural Dev. 10:1-14.

Uchida, S., K. H. Kim and I. S. Yun. 1989. The effect of wilting on silage making from the viewpoint in connection with monsoon Asia (A review). Asian-Aust. J. Anim. Sci. 2:43-49.

Udén, P. 2006. In vitro studies on microbial efficiency from two cuts of ryegrass (Lolium perenne, $c v$. Aberdart) with different proportions of sugars and protein. Anim. Feed Sci. Technol. 126:145-156.

Undersander, D., D. R. Mertens and N. Thiex. 1993. Forage analysis procedures. National Forage Testing Association, Omaha, Nebraska, USA.

Van Soest, P. J., J. B. Robertson and B. A. Lewis. 1991. Methods for dietary fibre, neutral detergent fibre and non-starch polysaccharides in relation to animal nutrition. J. Dairy Sci. 74:3583-3597.

Wanapat, M., S. Sriwattanasombat and S. Chantai. 1985. The utilization of diets containing untreated rice straw, ureaammonia treated rice straw and water hyacinth (Eichhornia crassipes, Mart). Trop. Anim. Prod. 10:50-57.

Weinberg, Z. G. and R. E. Muck. 1996. New trends and opportunities in the development and use of inoculants for silage. FEMS Microbiol. Rev. 19:53-68.

Weissbach, F. 1996. New developments in crop conservation. In: Proceedings of the XIth International Silage Conference, University of Wales, Aberystwyth, 8-11th September, 1996. pp. $11-25$.

Wilkins, R. 2005. Silage: A global perspective. In: Grasslands: Developments, Opportunities, Perspectives. (Ed. S. G. Reynolds and J. Frame), Science Publishers, Inc., New Hampshire, USA, pp. 111-132.

Wilkinson, J. M. 2005. Silage. Chalcombe Publications, Lincoln, United Kingdom.

Yokota, H., Y. Fujii and M. Ohshima. 1998. Nutritional quality of napier grass (Pennisetum purpureum Schum.) silage supplemented with molasses and rice bran by goats. AsianAust. J. Anim. Sci. 11:697-701. 